\title{
Effect of vermiwash of Eisenia foetida produced by different methods on seed germination of green mung, Vigna radiate
}

\author{
Amita Chattopadhyay ${ }^{1}$
}

Received: 18 November 2014/Accepted: 31 July 2015/Published online: 13 August 2015

(C) The Author(s) 2015. This article is published with open access at Springerlink.com

\begin{abstract}
Vermiwash contains enzymes, macro and micronutrients that could stimulate the growth and yield of crops. It can be prepared by different ways. In the present study, vermiwash was produced from the earthworm, Eisenia foetida, under field condition and also in the laboratory under cold and heat stress methods. These washes were used in different ratios for seed germination of mung, Vigna radiate. The results showed that the vermiwash produced by cold stress diluted at the ratio of 1:5 showed $100 \%$ germination of mung seed followed by 1:5 ratio vermiwash produced naturally that resulted $95 \%$ of seed germination. Undiluted vermiwash produced naturally and by cold stress showed $90 \%$ of germination of mung seed than the undiluted vermiwash produced by heat stress. Cold stress produced vermiwash diluted with 1:5 ratio showed a vigour index of 1650 followed by naturally produced 1:5 ratio diluted vermiwash which showed a vigour index of 1092. However, the undiluted naturally produced vermiwash showed the lowest vigour index of 450 .
\end{abstract}

Keywords Vermiwash - Eisenia foetida - Cold stress . Heat stress · Germination · Vigour index · Seed · Vigna radiate

\section{Introduction}

Earthworm's role as farmer's friend is well known since time immemorial. In recent times, the commercial vermin culturists have started promoting a product, called

Amita Chattopadhyay

mouami69@yahoo.com

1 Department of Science \& Technology, ICAR-Central Institute of Freshwater Aquaculture, Kausalyaganga, Bhubaneswar, Odisha 751002, India vermiwash. This vermiwash contains enzymes, secretions of earthwarms which would stimulate the growth and yield of crops and even develop resistance in crops receiving this spray (Shield 1982; Anand et al. 1995; Suthar et al. 2005; Yadav et al. 2005). Vermiwash also has soluble plant nutrients apart from some organic acids and mucus of earthworms and microbes (Shivsubramanian and Ganeshkumar 2004). Zambare et al. (2008) showed the effectiveness of vermiwash on cowpea plant growth by laboratory-scale trial. The effect of vermiwash was observed on the growth and productivity of Marigold (Shivsubramanian and Ganeshkumar 2004). The effect of vermiwash spray significantly increased dry chilli yield (George et al. 2007). Buckerfield et al. (1999) reported that weekly applications of vermiwash increased radish yield by $7.3 \%$. Thangavel (2003) also showed that both growth and paddy yield increased with the application of vermiwash and vermicast extracts. The present study was carried out to evaluate the effect of vermiwash on seed germination of green mung, Vigna radiate, in addition to the composition of vermiwash extracted by different methods and also to find out which method was more effective in seed germination.

\section{Materials and methods}

Vermiwash was extracted by three different methods which are as follows:

\section{Method I (heat stress method)}

This method was adopted from method described by Karuna et al. (1999). Well-grown adult earthworms Eisenia foetida were separated from casting materials by placing 
the worms in a plastic tub for some time. Then the earthworms were removed carefully from the casting materials and transferred to a glass beaker containing $500 \mathrm{ml}$ of warm $\left(40{ }^{\circ} \mathrm{C}\right.$ temperature) distilled water and agitated for 5-6 min with a stirrer. Around $30 \mathrm{~g}$ of warms were taken. They were then removed immediately and added to another pre-sterilized plastic container filled with water at room temperature. Here the worms were rinsed thoroughly to collect the remaining excretory and secretory products adhering to the body of the worms. The earthworms were then released back to the stock culture container. The light yellow straw-coloured contents of the glass beaker and plastic beaker were mixed and the solution was stored in sterilized dark colour glass bottle at $4{ }^{\circ} \mathrm{C}$ to be used for the experimental purpose.

\section{Method II (cold stress application)}

In this case, vermiwash was produced using method described by Pramanik (2010) with slight modification. Around 25 numbers having around $30 \mathrm{~g}$ of total weight of well-grown matured worms (E. foetida) of approximately equal length were applied cold stress by keeping them in chilled conditions, in ice cubes in beaker at $-5{ }^{\circ} \mathrm{C}$ for 3-4 min. The earthworms were then transferred to a 500 -ml glass beaker containing cold distilled $\left({ }^{\circ} \mathrm{C}\right)$ water and kept for 7-8 min with occasional stirring. The worms were transferred to a sterilized beaker containing distilled water at room temperature and rinsed for around 2-3 $\mathrm{min}$ and then released to the stock culture container. The light yellow-coloured exudutes from the petridish, glass beaker and plastic beaker were all mixed together and the vermiwash was stored in dark-coloured sterilized glass bottle at $4{ }^{\circ} \mathrm{C}$ for experimental purpose.

\section{Method III (field method)}

Vermiwash was collected from a vermiwash unit made up of a 15-1 plastic bucket with a tap fitted near the base. The lowermost part of the bucket was filled up to $20-25 \mathrm{~cm}$ with broken bricks and pebbles with a layer of coarse sand $(20-30 \mathrm{~cm})$ above it. On the top of the sand layer around $25 \mathrm{~cm}$ layer of moist loamy soil was laid. Finally, the unit was filled with a mixture of partially decomposed cowdung and other organic wastes. Around $1 \mathrm{~kg}$ (700-800 nos.) of earthworms (E. foetida) was released to the unit. Water was sprinkled on this unit overnight with the help of a perforated plastic container suspended above the unit. Every morning the tap was opened to collect the vermiwash, which was brought to the laboratory and stored in sterilized dark bottle at $4{ }^{\circ} \mathrm{C}$.

\section{Chemical analysis of vermiwash}

The organic carbon of vermiwash was determined using potassium di-chromate and concentrated sulphuric acid as extractants using hot water bath, and then followed the method of Walkley and Black (1934). Total N was determined in vermiwash samples by the Kjeldahl method using concentrated $\mathrm{H}_{2} \mathrm{SO}_{4}, \mathrm{~K}_{2} \mathrm{SO}_{4}$ and selenium to digest sample and was estimated according to Bremner and Mulvaney (1982). Total available $\mathrm{P}$ was determined by the colorimetric method of Olsen et al. (1954). Total potassium, sodium and calcium were determined by flame photometer. $\mathrm{pH}$ was estimated by $\mathrm{pH}$ meter while electrical conductivity was determined by a Conductivity meter. The vermiwash was also evaluated for the plant growth hormone indole acetic acid (IAA) by modified Salkowski's method (Gordon and Paleg 1957). Chemical compositions of vermiwash produced by different methods are presented in Table 1.

\section{Germination experiment}

Each petridish was layered with Whatman no. 1 filter and 10 healthy seeds of Vigna radiata; green mung were placed in each petridish. Treatments were maintained in triplicates. Ten different types of treatments including control
Table 1 Chemical composition of vermiwash produced by different methods

\begin{tabular}{|c|c|c|c|}
\hline Parameters & Vermiwash (heat stress) & Vermiwash (cold stress) & Vermiwash (field) \\
\hline $\mathrm{pH}$ & 7.98 & 7.40 & 7.52 \\
\hline E.C. $\left(\mathrm{dS} \mathrm{m} \mathrm{m}^{-1}\right)$ & 0.56 & 0.42 & 1.10 \\
\hline Organic carbon $(\%)$ & 0.042 & 0.036 & 0.009 \\
\hline Total nitrogen $\left(\mathrm{mg} \mathrm{L}^{-1}\right)$ & 55.0 & 52.0 & 61.02 \\
\hline Total phosphorus $\left(\mathrm{mg} \mathrm{L}^{-1}\right)$ & 19.15 & 17.80 & 18.20 \\
\hline Total potassium $\left(\mathrm{mg} \mathrm{L}^{-1}\right)$ & 46.24 & 45.20 & 55.20 \\
\hline Sodium $\left(\mathrm{mg} \mathrm{L}^{-1}\right)$ & 119.40 & 110.80 & 120.10 \\
\hline Calcium $\left(\mathrm{mg} \mathrm{L}^{-1}\right)$ & 181.08 & 175.25 & 178.60 \\
\hline Magnesium $\left(\mathrm{mg} \mathrm{L}^{-1}\right)$ & 196.34 & 186.90 & 198.00 \\
\hline IAA $\left(\mathrm{mg} \mathrm{L}^{-1}\right)$ & 16.08 & 15.05 & 15.02 \\
\hline
\end{tabular}


(with water only) were applied to the seeds. The seeds were soaked overnight in distilled water and then placed on the petridish. $5 \mathrm{ml}$ of test solution was added twice daily to the petridish for 6 days. Germination percentage was calculated on the 3rd day. At the end of the experiment, root length, shoot length and vigour index were estimated. The treatments included $\mathrm{T}_{1}$ (control, water only), $\mathrm{T}_{2}$ (heat stress vermiwash: water in the ratio $1: 1$ ); $\mathrm{T}_{3}$ (heat stress vermiwash: water in the ratio 1:5); $\mathrm{T}_{4}$ (cold stress vermiwash: water in the ratio $1: 1$ ); $\mathrm{T}_{5}$ (cold stress vermiwash: water in the ratio 1:5); $\mathrm{T}_{6}$ (vermiwash produced normally: water in the ratio $1: 1$ ); $\mathrm{T}_{7}$ (vermiwash produced normally: water in the ratio 1:5); $\mathrm{T}_{8}$ (undiluted heat stress vermiwash); $\mathrm{T}_{9}$ (undiluted cold stress vermiwash); $\mathrm{T}_{10}$ (undiluted normally produced vermiwash). The two dilutions 1:1 and 1:5 for all the cases were made arbitrarily. The periodic addition of vermiwash was used from the same stock solutions; only the dilutions were made freshly.

\section{Statistical analysis}

All the reported data are mean $\pm \mathrm{SD}$ of three replicates. The one-way analysis of variance (ANOVA) was used to analyse the significant germination difference, difference in length of seedlings between vermiwash of different extraction types and dilution using statistical software SPSS (14.0 version).

\section{Results and discussion}

\section{Germination percentage}

The effect of different treatments on germination of seeds of green mung has been shown in Table 2. One-way
ANOVA followed by Turkey's post hoc test showed that there was statistically significant difference $(F=15.455$, $P<0.05)$ of germination percentage between the control $(65 \%)$ and all the other treatments, all of which showed above $80 \%$ germination. The variance among different treatment groups was found to be homogeneous as per Levene's test of homogeneity of variance where Levene's F-statistic had a value of 0.871 which was greater than 0.05 . There was $100 \%$ germination in the seeds treated with $\mathrm{T}_{5}$, i.e., 1:5 ratio diluted vermiwash produced from cold stress, followed by 1:5 ratio diluted vermiwash produced naturally. The vermiwash produced by cold stress was superior compared to the same produced by heat stress in seed germination. In heat stress, enzymes could be denatured. Moreover, there could be a chance of release of more amounts of micronutrients, i.e., $\mathrm{Fe}, \mathrm{Cu}, \mathrm{Zn}$ and $\mathrm{Mn}$ in heat stress vermiwash. Though micronutrients are helpful in seed germination, greater amounts could be toxic at the same time.

\section{Root and shoot length}

In all the cases, root and shoot length was superior over control. One-way ANOVA followed by Turkey's post hoc test revealed that there was statistical significant difference ( $F=47.122, P<0.05)$ of average length of seedlings between the control and all the other treatments. The variances among different treatment groups were homogeneous as per Levene's test of homogeneity of variance table where Levene's F statistic had a value of 0.456 which was greater than 0.05 . The maximum root length $6.5 \mathrm{~cm}$ and the maximum root length $10 \mathrm{~cm}$ were observed at 1:5 ratio of vermiwash produced by cold stress. The minimum root length of $2-3 \mathrm{~cm}$ and the minimum shoot length of $3.0-3.5 \mathrm{~cm}$ were observed at the undiluted vermiwash

Table 2 Effect of vermiwash on seedlings, germination and vigour of green mung, Vigna radiate

\begin{tabular}{|c|c|c|c|c|c|}
\hline Treatments & $\begin{array}{l}\text { Root length } \\
(\mathrm{cm}) \\
(\text { mean } \pm \mathrm{SD})\end{array}$ & $\begin{array}{l}\text { Shoot length } \\
(\mathrm{cm}) \\
(\text { mean } \pm \mathrm{SD})\end{array}$ & $\begin{array}{l}\text { Average length } \\
\text { of seedlings }(\mathrm{cm}) \\
\text { (L) }(\text { mean } \pm \mathrm{SD})\end{array}$ & $\begin{array}{l}\text { Germination }(\%) \\
(\mathrm{G})(\text { mean } \pm \mathrm{SD})\end{array}$ & $\begin{array}{l}\text { Vigour } \\
\text { index } \\
(\mathrm{L} \text { X G) }\end{array}$ \\
\hline $\mathrm{T}_{1}$ (Control, water only) & $3.0 \pm 0.2$ & $5.0 \pm 0.3$ & $8.0 \pm 0.5$ & $65 \pm 5$ & 520 \\
\hline $\mathrm{T}_{2}$ (Heat stress vermiwash: water in the ratio $1: 1$ ) & $3.0 \pm 0.3$ & $5.0 \pm 0.3$ & $8.0 \pm 0.6$ & $80 \pm 6$ & 640 \\
\hline $\mathrm{T}_{3}$ (Heat stress vermiwash: water in the ratio $1: 5$ ) & $4.0 \pm 0.4$ & $4.0 \pm 0.3$ & $8.0 \pm 0.7$ & $80 \pm 5$ & 640 \\
\hline $\mathrm{T}_{4}$ (Cold stress vermiwash: water in the ratio $1: 1$ ) & $4.0 \pm 0.2$ & $4.5 \pm 0.3$ & $8.5 \pm 0.5$ & $70 \pm 5$ & 595 \\
\hline $\mathrm{T}_{5}$ (Cold stress vermiwash: water in the ratio $1: 5$ ) & $6.5 \pm 0.8$ & $10.0 \pm 0.7$ & $16.5 \pm 1.5$ & 100 & 1650 \\
\hline $\mathrm{T}_{6}$ (Vermiwash produced normally: water in the ratio $1: 1$ ) & $4.0 \pm 0.6$ & $6.0 \pm 0.6$ & $10.0 \pm 1.2$ & $80 \pm 5$ & 800 \\
\hline $\mathrm{T}_{7}$ (Vermiwash produced normally: water in the ratio $1: 5$ ) & $5.5 \pm 0.9$ & $6.0 \pm 0.5$ & $11.5 \pm 1.4$ & $95 \pm 5$ & 1092.5 \\
\hline $\mathrm{T}_{8}$ (Undiluted heat stress vermiwash) & $2.5 \pm 0.2$ & $3.0 \pm 0.3$ & $5.5 \pm 0.5$ & $85 \pm 5$ & 467.5 \\
\hline $\mathrm{T}_{9}$ (Undiluted cold stress vermiwash) & $2.0 \pm 0.2$ & $3.5 \pm 0.2$ & $5.5 \pm 0.4$ & $90 \pm 5$ & 495 \\
\hline $\mathrm{T}_{10}$ (Undiluted normally produced vermiwash) & $2.0 \pm 0.1$ & $3.0 \pm 0.2$ & $5.0 \pm 0.3$ & $90 \pm 4$ & 450 \\
\hline
\end{tabular}


produced either naturally or by cold stress or by heat stress. This could be due the presence of toxicity effects of higher concentrations of nutrients in the undiluted vermiwash. The vigour index was highest at 1:5 ratio diluted vermiwash produced by cold stress followed by 1:5 ratio diluted vermiwash produced naturally. In response to vermiwash application, $V$. radiate seedlings produced a profuse growth of fine root hairs, which was not found in the seedlings that received only water. The profuse root hair growth was direct indication of involvement of IAA present in vermiwash (Gopal et al. 2010).

Provitamin D (Zrazhevsky 1957) and vitamin B (Atlavinyte et al. 1971) are reported up to a considerable level in earthworm products and probably these act as promoters for carbohydrate and protein metabolism in vermiwashtreated seedlings. Vermiwash is a collection of excretory products and excess secretions of earthworms along with micronutrients from soil organic molecules. Zambare et al. (2008) reported that boiled water extract vermiwash contained amylase and protease enzymes. They also reported that vermiwash contained nitrogen and phosphate solubilizing bacteria. Prabhu (2006) reported that vermiwash improved the germination percentage of the seeds and seedling vigour of seeds such as cowpea and paddy crops. The presence of proteases in vermiwash could help in seed germination while amylases could help for availability of simple carbon source for enhancement of plant growth and productivity (Zambare et al. 2008).

In the present study, it was evident that undiluted vermiwash was phytotoxic to $V$. radiate as it significantly reduced the percentage of germination and seedling's length of the test crop. It was also observed that in the undiluted vermiwash treatment, the roots had turned brown and had a charred appearance. The diluted vermiwash (1:1-1:5) was able to increase the seed germination percentage and the seedlings' vigour index when compared to water.

\section{Conclusion}

From the present study, it is evident that the nutrients and growth promoting substances present in the vermiwash showed its potentiality in seed germination and seedling vigour. However, the vermiwash produced by cold stress diluted at the ratio of 1:5 produced superior result followed by $1: 5$ ratio vermiwash produced naturally, i.e. without stress. The use and application of vermiwash could play a beneficial role in sustainable agriculture as it is environment friendly, cost effective, reliable and easily available.

Acknowledgments The author is grateful to the Department of Science and Technology, New Delhi, India for providing the Project under the Women Scientist Scheme (Science and Society) and fellowship. The author is also grateful to the Director, ICAR-CIFA, Bhubaneswar, India for providing laboratory and field facilities to carry out the work.

\section{Compliance with ethical standards}

Conflict of interest The authors declare that there is no conflict of interest.

Open Access This article is distributed under the terms of the Creative Commons Attribution 4.0 International License (http://crea tivecommons.org/licenses/by/4.0/), which permits unrestricted use, distribution, and reproduction in any medium, provided you give appropriate credit to the original author(s) and the source, provide a link to the Creative Commons license, and indicate if changes were made.

\section{References}

Anand JA, Wilson MDP, Kale RD (1995) Effect of vermiwash on seed germination and seedling growth. J Soil Biol Ecol 15:90-95

Atlavinyte O, Daciulyte J, Luganska A (1971) Correlation between the number of earthworm, microorganisms and $B_{12}$ in soil fertilized with straw. Liet TSR Moksulu Akad Darb Ser B 3:43-56

Bremner JM, Mulvaney CS (1982) Nitrogen \pm total. In: Page AL, Miller RH, Keeney (eds) Methods of soil analysis. Part 2, Chemical and microbiological properties. American Society of Agronomy, Madison, pp 595-641

Buckerfield JC, Flavel TC, Lee KE, Webster KA, Diazcozin DJ, Jesus JB, Trigo D, Garvin MH (1999) Vermicompost in solid and liquid forms as a plant growth promoter. 6th international symposium on earthworm ecology, Vigo, Sain, 1998. Pedobiologia 43:753-759

George S, Giraddi RS, Patil RH (2007) Utility of vermiwash for the management of Thrips and Mites on chilli (Capsicum annuum L.) amended with soil organics. Karnataka J Agric Sci 20:657-659

Gopal M, Gupta A, Palaniswami C, Dhanapal R, Thomas GV (2010) Coconut leaf vermiwash: a bio-liquid from coconut leaf vermicompost for improving the crop production capacities of soil. Curr Sci 98(9):1202-1210

Gordon SA, Paleg LG (1957) Quantitative measurement of indole acetic acid. Physiol Plant 10:37-48

Karuna K, Patil CR, Narayanswamy P (1999) Kale stimulatory effects of earthworm body fluid (vermiwash) on Crinkle red Varity of Vnthurium andreanum Lind. Crop Res 17(2):253-257

Olsen SR, Cole CV, Watanabe FS, Dean LA (1954) Estimation of Available Phosphorous in Soil by Extraction with Sodium Bicarbonate. USDA Circular 939, Government Printing Office, Washington, DC

Parmanik P (2010) Quantification of hydrolic and proteolytic enzymes in the excreta of three epigeic earthworms and detection of thiocarbamic acid by GC-MS-MS. Environmentalist $30: 212-215$

Prabhu MJ (2006) Coconut leaf vermiwash stimulates crop yield. The Hindu Newspaper, 28th December, In: Science and Technology section

Shield EB (1982) Raising earthworms for profit. Shields Publication. PO Box 669 Eagle River Wisconsin, 128 p

Shivsubramanian K, Ganeshkumar M (2004) Influence of vermiwash on biological productivity of Marigold. Madras Agric J 91:221-225 
Suthar S, Choyal RR, Singh S, Sudesh R (2005) Stimulatory effect of earthworm body fluid on seed germination and seedlings growth of two legumes. J Phytol Res 1(2):219-222

Thangavel P, Balagurunathan R, Divakaran J, Prabhakaran J (2003) Effect of vermiwash and vermicast extraction soil nutrient status, growth and yield of paddy. Adv Plant Sci 16:187-190

Walkley A, Black IA (1934) An examination of Degtjareff method for determining soil organic matter and a proposed modification of the chromic acid titration method. Soil Sci 37:29-37
Yadav AK, Kumar K, Singh S, Sharma M (2005) Vermiwash-A liquid biofertilizer. UP J Zool 25(1):97-99

Zambare VP, Padul MV, Yadav AA, Shete TB (2008) Vermiwash: biochemical and microbiological approach asecofriendly soil conditioner. ARPN J Agric Biol Sci 3(4):1-5

Zrazhevsky AI (1957) Dozdevye cervi kak factor plodorodija lesnych prov Akad.Nauk Ukr, SSR, Kiew 